\title{
Presentación de la Ley de Conciliación Ley No 26872
}

\section{Aníbal Quiroga León}

El 13 de noviembre de 1997 se publicó en el Diario Oficial «El Peruano» la Ley No 26872, denominada «Ley de Conciliación». Dicha norma legal está actualmente bajo vacatio legis como consecuencia de las diferentes normas legales que han postergado su aplicación en el tiempo, pues prevista inicialmente para ingresar en vigencia a los dos años de su publicación (14 de enero de 2000), la imposibilidad de lograr su aplicación forzosa en todo el territorio nacional y el riesgo de su inadecuada implementación, han dispuesto que esto ocurra recién el 14 de enero del año 2001.

Así pues, la ley original -que hoy publicamos en esta edición como anexo de esta Presentación-, aún no se encuentra en vigencia debido a la imposibilidad de contar con la infraestructura y conocimiento necesarios que permitan su total implementación en nuestro medio jurídico.

La Conciliación es, básicamente, una figura procesal. Muchas veces tendemos a pensar -de modo equívoco, por cierto- que lo procesal es siempre litigioso, siempre controversial, siempre guerrero; de manera que figuras como la Conciliación deberían estar fuera de lo procesal por ser institutos incompatibles. Si miramos con detenimiento dentro de la Teoría del Proceso, y su ciencia, veremos que la Conciliación es una de las formas que el proceso nos proporciona para lograr la solución de un conflicto de manera pacífica. Es, pues, un modo pacífico de solución de controversias, a mitad de camino entre la fórmula autocompositiva y la forma heterocompositiva. En términos reales, constituye una forma anterior de solución procesal a la que provee la heterocomposición procesalizada que está a cargo, de modo exclusivo 
y excluyente, del Poder Judicial por mandato de nuestro esquema constitucional.

Corresponde la Conciliación, en consecuencia, a una etapa anterior a la del proceso judicial jurisdiccional, conforme señala la propia Ley de Conciliación. Esta norma tiene por finalidad descongestionar al Poder Judicial de un importante número de causas que, bien manejadas por las partes de modo directo, bajo la inducción de un Conciliador imparcial, le impiden actuar dentro de plazos razonables que la ley y el principio de razonabilidad consideran los adecuados para la resolución de una controversia. Se pretende con la implementación y obligatoriedad de esta institución del Derecho Procesal desviar del órgano jurisdiccional el aumento innecesario de litigios en nuestra sociedad, bajo una adecuada técnica jurídica de negociación y persuasión, buscando con ello que las partes interesadas en su conflicto, reflexionen acerca de los puntos comunes que les acercan, quitándoloe la innecesaria litigiosidad y con ello instaurar una "Cultura de paz" por la cual aquellos particulares que tengan un conflicto de intereses, de modo previo a la solicitud de actuación de la autoridad judicial competente, busquen la posibilidad de arribar a un acuerdo razonable y satisfactorio para ambas.

Como se podrá apreciar de modo directo con la ley que ahora presentamos, a la par de los importantes trabajos que desarrollan esta institución con gran versación y calidad, en el proceso conciliatorio tendrá intervención un tercero cuya misión será la de encaminar el proceso de tal modo que la fórmula conciliatoria a la cual se arribe sea una que imponga un nuevo estatus jurídico definitivo para las partes, será también función de este tercero proponer alternativas de solución previas a la decisión de acudir al poder judicial.

La obligatoriedad de acudir al proceso conciliatorio antes de ingresar al proceso judicial, como requisito sine qua non de éste, tiene por finalidad la disminución del ingreso de nuevas causas judiciales cuya tramitación supone un costo tanto para las partes como para el Estado. Ahora bien, esta obligatoriedad se refiere al proceso de conciliación, no así a que las partes deban necesariamente resolver sus controversias. Finalmente cabe señalar, que este rasgo de obligatoriedad que se ha plasmado en la Ley de Conciliación también estará presente en el cumplimiento del acuerdo al cual arriben las partes, pues caso contrario se requerirá el apoyo de la autoridad judicial para su ejecución. 
Al igual que la transacción judicial y la transacción extrajudicial la mediación o la amigable composición, la conciliación judicial preventiva (como es el caso de la Ley de Conciliación) responde a la moderna denominación de ADR (Alternative dispute resolution), cuya impropia traducción al español la señala como «medios alternativos de solución de controversias", constituyendo mecanismos anteriores -antes que propiamente "alternativos» -a la solución adecuada de una controversia mediante la posibilidad de que las mismas partes interesadas logren esto evitando la actuación y costo del órgano judicial, y con ello obstar la innecesaria intervención del Estado para la solución de los conflictos jurídicamente relevantes que se den entre sus ciudadanos y que estos mismos, en el contexto de la autonomía y libre disponibilidad de los derechos.

«Ley No 26872.- Aprueba Ley de Conciliación Extrajudicial.- (1311-1997)

\section{Ley No 26872}

El Presidente de la República

Por cuanto :

El Congreso de la República ha dado la ley siguiente.

El Congreso de la República;

Ha dado la ley siguiente:

Ley de Conciliación

\section{Capítulo I.- Principios generales}

Artículo $1^{o}$.- Interés nacional.- Declárese de interés nacional la institucionalización y desarrollo de la Conciliación como mecanismo alternativo de solución de conflictos.

Artículo $2^{\circ}$.- Principios.- La Conciliación propicia una cultura de paz y se realiza siguiendo los principios éticos de equidad, veracidad, buena fe, confidencialidad, imparcialidad, neutralidad, legalidad, celeridad y economía.

Artículo $3^{\circ}$.- Autonomía de la voluntad.- La Conciliación es una institución consensual, en tal sentido, los acuerdos adoptados obedecen única y exclusivamente a la voluntad de las partes.

Artículo $4^{\circ}$. - Función no jurisdiccional.- La Conciliación no constituye acto jurisdiccional. 


\section{Capítulo II.- De la Conciliación}

Artículo $5^{\circ}$.- Definición.- La Conciliación extrajudicial es una institución que se constituye como un mecanismo alternativo para la solución de conflictos, por el cual las partes acuden ante un Centro de Conciliación o al Juzgado de Paz Letrado a fin que se les asista en la búsqueda de una solución consensual al conflicto.

Artículo $6^{\circ}$.- Carácter obligatorio.- La Conciliación es un requisito de procedibilidad necesariamente previo a los procesos a que se refiere el Artículo 9.

La Conciliación Extrajudicial no es obligatoria cuando la parte emplazada domicilia en el extranjero y en los procesos cautelares, de ejecución y de garantías constitucionales.

Artículo $7^{\circ}$.- Vías alternativas.- En la Conciliación Extrajudicial las partes pueden optar de manera excluyente por los Centros de Conciliación o recurrir ante los Jueces de Paz Letrados.

Artículo $8^{\circ}$.- Confidencialidad.- Los que participan en la Conciliación deben mantener reserva de lo actuado. Nada de lo que se diga o proponga tendrá valor probatorio.

Artículo $9^{\circ}$. - Materias conciliables.- Son materia de Conciliación las pretensiones determinadas o determinables que versen sobre derechos disponibles de las partes.

En asuntos relacionados al derecho de familia se someten al procedimiento establecido en la presente ley las pretensiones que versen sobre alimentos, régimen de visitas y violencia familiar.

No se someten a Conciliación Extrajudicial las controversias sobre hechos que se refieran a la comisión de delitos o faltas, con excepción de las controversias relativas a la cuantía de la reparación civil derivada de la comisión de delitos, en cuanto ella no hubiera sido fijada por resolución judicial firme.

Artículo 10\%.- Audiencia única.- La Audiencia de Conciliación es una y comprende la sesión o sesiones necesarias para el cumplimiento de los fines previstos en la presente ley.

Artículo 11 ${ }^{\circ}$.- Plazo.- El plazo de la Audiencia de Conciliación es de treinta (30) días calendario contados a partir de la primera citación a las partes. El plazo previsto puede ser prorrogado por acuerdo de las partes.

Artículo $12^{\circ}$.- Fecha de Audiencia.- Recibida la solicitud el Centro de Conciliación designa al conciliador y éste a su vez notifica a las partes dentro de los cincuenta días útiles siguientes. La Audiencia de 
Conciliación se realiza dentro de los diez (10) días útiles contados a partir de la primera notificación.

Artículo 13․- Petición.- Las partes pueden solicitar la Conciliación Extrajudicial en forma conjunta o individual, con arreglo a las reglas generales de competencia establecidas en el Artículo $14^{\circ}$ del Código Procesal Civil.

Artículo 14\%.- Concurrencia.- La concurrencia a la Audiencia de Conciliación es personal; salvo las personas que conforme a ley deban actuar a través de representantes legales.

En el caso de personas domiciliadas en el extranjero se admitirá el apersonamiento a la Audiencia de Conciliación a través de apoderado o tratándose de personas jurídicas, sus representantes legales en el país. Artículo 150.- Conclusión de la Conciliación.- Se da por concluida la Conciliación por:

1. Acuerdo total de las partes.

2. Acuerdo parcial de las partes.

3. Falta de acuerdo entre las partes.

4. Inasistencia de una parte a dos (2) sesiones.

5. Inasistencia de las partes a una (1) sesión. Articulo 16 ${ }^{\circ}$. Acta.- El Acta es el documento que expresa la manifestación de voluntad de las partes en la Conciliación Extrajudicial. Su validez está condicionada a la observancia de las formalidades establecidas en la presente ley, bajo sanción de nulidad.

El Acta de Conciliación debe contener lo siguiente:

1. Lugar y fecha en la que se suscribe el acta.

2. Nombres, identificación y domicilio de las partes.

3. Nombre e identificación del conciliador.

4. Descripción de las controversias.

5. El Acuerdo Conciliatorio, sea total o parcial, estableciendo de manera precisa los derechos, deberes u obligaciones ciertas, expresas y exigibles; o en su caso la falta de acuerdo o la inasistencia de las partes a la audiencia.

6. Firma y huella digital del conciliador, de las partes o de sus representantes legales, cuando asistan a la audiencia.

En caso de las personas que no saben firmar bastará la huella digital.

7. Nombre y firma del abogado del Centro de Conciliación, quien verificará la legalidad de los acuerdos adoptados.

El acta en ningún caso debe contener las propuestas o la posición de una de las partes respecto de éstas. 
Artículo $17^{\circ}$ - Conciliación parcial.- Si la Conciliación concluye con acuerdo parcial, sólo puede solicitarse tutela jurisdiccional efectiva por las diferencias no resueltas.

Articulo 18 $8^{\circ}$ - Mérito y ejecución del Acta de conciliación.- El acta con acuerdo conciliatorio constituye título de ejecución.

Los derechos, deberes u obligaciones ciertas, expresas y exigibles que consten en dicha acta son exigibles a través del proceso de ejecución de resoluciones judiciales.

Artículo $19^{\circ}$.- Prescripción y caducidad.- Los plazos de prescripción y caducidad establecidos en el Código Civl se suspenden a partir de la fecha de presentación de la solicitud de Conciliación Extrajudicial.

\section{Capítulo III.- Del Conciliador}

Articulo 20 $0^{\circ}$ - Funciones.- El conciliador es la persona capacitada y acreditada que cumple labores en un Centro de Conciliación, propicia el proceso de comunicación entre las partes y eventualmente propone fórmulas conciliatorias no obligatorias.

Artículo 21 $1^{\circ}$ - Libertad de Acción.- El conciliador conduce la Audiencia de Conciliación con libertad de acción, siguiendo los principios establecidos en la presente ley.

Artículo $22^{\circ}$.- Requisitos de los conciliadores.- Para ser conciliador se requiere estar acreditado en un Centro de Conciliación y capacitado en técnicas de negociación y en medios alternativos de solución de conflictos.

Artículo $23^{\circ}$.- Impedimento, recusación y abstención de conciliadores.- Son aplicables a los conciliadores las causales de impedimento, recusación y abstención establecidas en el Código Procesal Civil.

\section{Capítulo IV.- De los Centros de Conciliación}

Artículo 240.- De los Centros de Conciliación.- Los Centros de Conciliación son entidades que tienen por objeto ejercer función conciliadora de conformidad con la presente ley.

Pueden constituir Centros de Conciliación las personas jurídicas de derecho público o privado sin fines de lucro, que tengan entre sus finalidades el ejercicio de la función conciliadora.

En caso que los servicios del Centro de Conciliación sean onerosos, la retribución será pagada por quien solicita la conciliación, salvo pacto en contrario, que deberá constar en el acta correspondiente. 
Artículo 250.- Capacitación de los conciliadores.- Los Centros de Conciliación son responsbles por la capacitación de los conciliadores y de que éstos cumplan con los principios establecidos en el Artículo $2^{\circ}$ de la presente ley.

Artículo $26^{\circ}$. - Autorización y supervisión.- El Ministerio de Justicia tiene a su cargo la autorización de funcionamiento, registro y supervisión de los Centros de Conciliación, pudiendo suspender o privar de su facultad conciliadora, cuando éstos no cumplan con los principios u objetivos legales previstos en la presente ley, o incurran en faltas éticas.

Articulo $27^{\circ}$.- Requisitos.- Las instituciones que soliciten la aprobación de centros deben adjuntar a su solicitud debidamente suscrita por su representante legal, lo siguiente:

1. Documentos que acrediten la existencia de I ainstitución.

2. Dcoumentos que acrediten la representación.

3. Reglametno del Centro.

4. Relación de conciliadores.

Articulo 28 $8^{\circ}$ - Del registro de Actas de Conciliación.- Cada Centro de Conciliación llevará un Registro de Actas, del cual se expedirán copias certificadas a pedido de parte.

En caso de destrucción, deterioro, pérdida o sustracción parcial o total del Acta de Conciliación, debe comunicarse inmediatamente al Ministerio de Justicia quien procederá conforme a lo dispuesto en el Artículo $26^{\circ}$ de la presente ley, sin perjuicio de las acciones civiles o penales que correspondan.

Articulo 29 .- Legalidad de los acuerdos.- El Centro de Conciliación contará por lo menos con un abogado quien supervisará la legalidad de los acuerdos conciliatorios.

Artículo 30\%.- Información estadística.- Los Centros de Conciliación deben elaborar semestralmente los resultados estadísticos de su institución, los mismos que deben ser remitidos al Ministerio de Justicia, exhibidos y difundidos para conocimiento del público.

Capítulo V.- De la Junta Nacional de Centros de Conciliación Artículo $31^{\circ}$.- Junta Nacional de Conciliación.- La Junta Nacional de Centros de Conciliación se constituye como una persona jurídica de derecho privado que integra a los Centros de Conciliación.

La Asamblea elige a su primera directiva y aprueba sus estatutos. Artículo $32^{\circ}$.- Funciones.- Son funciones de la Junta Nacional de 
Centros de Conciliación las siguientes :

1. Coordinar sus acciones a nivel nacional;

2. Promover la eficiencia de los centros;

3. Difundir la institución de la Conciliación como mecanismo alternativo de solución de conflictos; $y$,

4. Coordinar con el Ministerio de Justicia los asuntos derivados de la aplicación de la presente ley.

Capítulo VI.- De la Conciliación ante los Jueces de Paz Artículo $33^{\circ}$.- Jueces de Paz.- La Conciliación se lleva a cabo ante el Juez de Paz Letrado y a falta de estos ante el Juez de Paz.

Artículo 34\%.- Procedimiento.- El procedimiento de Conciliación que se sigue ante los Juzgados de Paz es el que establece la presente ley.

Artículo $35^{\circ}$.- Responsabilidad disciplinaria.- Los Jueces que actúan como conciliadores se sujetan a las responsabilidades disciplinarias establecidas en la Ley Orgánica del Poder Judicial.

Articulo 36 .- Tasas por Servicios Administrativos.- Los gastos administrativos derivados de la Conciliación ante los Juzgados generan el pago de una tasa por servicios administrativos.

Artículo $37^{\circ}$.- Mérito y Ejecución del Acta.- El mérito y el proceso de ejecución del acta con acuerdo conciliatorio adoptado ante los jueces, es el mismo establecido en el Artículo $18^{\circ}$ de la presente ley.

Artículo 38 ${ }^{\circ}$.- Registro de Actas de Conciliación.- Los Juzgados de Paz crearán el Libro de Registros de Actas de Conciliación, de donde se expedirán las copias certificadas que soliciten las partes.

Disposiciones complementarias, transitorias y finales

Primera.-Vigencia.- La presente ley entra en vigencia a partir de los sesenta días siguientes a su publicación.

Segunda.- Reglamentación.- La presente ley será reglamentada en el plazo establecido en la disposición anterior.

Tercera.- Suspensión de la obligatoriedad.- La obligatoriedad a que se refiere el Artículo $6^{\circ}$ rige a partir de los veinticuatro (24) meses siguientes a la entrada en vigencia de la presente ley. Durante el período intermedio el procedimiento de Conciliación regulado en la presente ley será facultativo.

Cuarta.- Centros Preexistentes.- Las entidades que hayan realizado conciliaciones antes de la vigencia de la presente ley pueden adecuarse a ésta dentro de los doce (12) meses contados a partir de su vigencia. 
Las entidades que dentro del plazo establecido en el párrafo precedente no se hayan adecuado a la presente ley, continuarán funcionando de conformidad con las normas legales e institucionales que las regulan. Las actas derivadas de las conciliaciones que realicen no tienen mérito de título de ejecución.

Quinta.- Requisitos de admisibilidad.- Incorpórase el inciso 7) al Artículo $425^{\circ}$ del Código Procesal Civil:

«7. Copia certificada del Acta de Conciliación Extrajudicial, en los procesos judiciales cuya materia se encuentre sujeta a dicho procedimiento previo".

Sexta.- Vigencia del requisito de admisibilidad.- El requisito establecido en la disposición precedente será exigible una vez se encuentre en vigencia la obligatoriedad a que se refiere el Artículo $6^{\circ}$ de la presente ley.

Sétima.- Conciliación Extrajudicial.- El procedimiento de Conciliación creado en la presente ley se realiza de modo independiente de aquel que regula el Código Procesal Civil.

Comuníquese al señor Presidente de la República para su promulgación.

En Lima, a los veintinueve días del mes de octubre de mil novecientos noventa y siete.

Carlos Torres y Torres Lara. Presidente del Congreso de la República. Edith Mellado Céspedes. Primera Vicepresidenta del Congreso de la República.

Al señor Presidente Constitucional de la República

Por tanto:

Mando se publique y cumpla.

Dado en la Casa de Gobierno, en Lima, a los doce días del mes de noviembre de mil novecientos noventa y siete.

Alberto Fujimori Fujimori. Presidente Constitucional de la República. Alberto Pandolfi Arbulú. Presidente del Consejo de Ministros. Alfredo Quispe Correa. Ministro de Justicia. "*

* Tomado de Normas Legales, Tomo 258, Noviembre 1997, pp. 175-177. 


\section{«D.S. No 001-98-JUS. -Aprueba el Reglamento de la Ley de Conciliación (14/01/98)}

\section{DECRETO SUPREMO No 001-98-JUS}

El Presidente de la República

Considerando:

Que, mediante Ley No 26872 (T.258,106) se declara de interés nacional la institucionalización y desarrollo de la Conciliación como mecanismo alternativo de resolución de conflictos:

Que, la Segunda Disposición Complementaria, Transitoria y Final de la indicada ley dispone que la misma debe ser reglamentada en el plazo de sesenta días contados a partir del día siguiente de su publicación;

De conformidad con el Artículo 118 Política del Perú (T.211, 213);

Decreta:

Artículo $1^{\circ}$. - Apruébase el Reglamento de la Ley No 26872 - Ley de Conciliación, el mismo que consta de siete (7) títulos, setenta y cinco (75) artículos y seis (6) disposiciones complementarias, transitorias y finales.

Articulo $2^{\circ}$.- El presente Decreto Supremo será refrendado por el Ministro de Justicia.

Dado en la Casa de Gobierno, en Lima, a los trece días del mes de enero de mil novecientos noventa y ocho.

Alberto Fujimori Fujimori, Presidente Constitucional de la República, Alberto Pandolfi Arbulú, Presidente del Consejo de Ministros.

\section{Reglamento de la Ley de Conciliación \\ Título I.- Principios Generales}

Artículo $1^{o}$.- El presente Reglamento norma la naturaleza, finalidad, funciones, requisitos y el procedimiento aplicable a la Conciliación como mecanismo extrajudicial de solución de conflictos.

Cuando en el Reglamento se haga mención a la ley, se entenderá que la referencia es a la Ley de Conciliación.

La Conciliación Procesal está regulada en el Código Procesal Civil. Artículo $2^{\circ}$. Para los efectos de la aplicación del Artículo $2^{\circ}$ de la ley, deberá tenerse en cuenta de manera referencial, el siguiente contenido de los principios ahí anunciados: 
1. La equidad, debe ser concebida como el sentido de la justicia aplicada al caso particular, materia de conciliación.

2. La veracidad, está dirigida a la búsqueda de lo querido realmente por las partes y se refleja en el acuerdo conciliatorio al que llegarán de manera libre, como la mejor solución para ambas.

3. La buena fe se entiende como la necesidad de que las partes procedan de manera honesta y leal, confiando en que esa será la conducta en el procedimiento de conciliación.

4. La confidencialidad supone que, tanto el conciliador como las partes, deben guardar absoluta reserva de todo lo sostenido o propuesto.

5. La imparcialidad y la neutralidad son garantías de seguridad y justicia. La intervención del conciliador durante el procedimiento de conciliación será sin identificación alguna con los intereses de las partes.

6. La legalidad expresa la conformidad del acuerdo conciliatorio al que arriben las partes, con el ordenamiento jurídico.

7. La celeridad es consustancial al procedimiento de conciliación, permitiendo la solución pronta y rápida del conflicto.

8. La economía está dirigida a que las partes eliminen el tiempo que les demandaría estar involucradas en un proceso judicial, ahorrando los costos de dicho proceso.

Artículo $3^{\circ}$.- La Conciliación es el acto jurídico por medio del cual las partes buscan solucionar su conflicto de intereses, con la ayuda de un tercero llamado conciliador. Se funda en el principio de la autonomía de la voluntad.

Artículo $4^{o}$.- El acuerdo conciliatorio es fiel expresión de la voluntad de las partes y del consenso al que han llegado para solucionar sus diferencias. La validez de dicho acuerdo está sujeta a la observancia de las formalidades solemnes, previstas en el Artículo $16^{\circ}$ de la ley, bajo sanción de nulidad.

Artículo $5^{\circ}$ - La autonomía de la voluntad a que hace referencia el Artículo $3^{\circ}$ de la ley, no se ejerce irrestrictamente. Las partes pueden disponer de sus derechos siempre y cuando no afecten con ello normas de carácter imperativo ni contraríen el orden público ni las buenas costumbres. 


\section{Título II.- De la Conciliación}

Articulo $6^{\circ}$.- De conformidad con los Artículos $5^{\circ}$ y $13^{\circ}$ de la ley, la Conciliación puede ser solicitada por cualquiera de las partes, o por ambas, a un Centro de Conciliación o ante un Juez de Paz Letrado con el objeto que un tercero llamado conciliador, le asista en la búsqueda de una solución consensual al conflicto.

Artículo $7^{\circ}$.- De acuerdo con la ley, la Conciliación puede ser:

1. Por la iniciativa de las partes:

a) Obligatoria:

Para los casos de derechos disponibles. Entiéndase por derechos disponibles aquellos que tienen un contenido patrimonial; es decir, los que son susceptibles de ser valorados económicamente. Son también derechos disponibles aquellos que, no siendo necesariamente patrimoniales, pueden ser objeto de libre disposición.

De acuerdo con lo dispuesto en el Artículo $9^{0}$ de la ley, y para efectos de la Conciliación, en los asuntos relativos a alimentos, régimen de visitas, violencia familiar y la responsabilidad civil proveniente de delito, sólo son conciliables los derechos de libre disposición.

La Conciliación en asuntos laborales supone el respeto de los derechos intangibles del trabajador, por lo que sólo opera en el ámbito de disponibilidad que éste disfruta.

b) Facultativa:

- De acuerdo con lo establecido en el segundo párrafo del Artículo $6^{\circ}$ de la ley, cuando la parte emplazada domicilia en el extranjero y en los procesos cautelares, de ejecución y de garantías constitucionales.

- Cuando las partes han convenido que cualquier discrepancia entre ellas se solucionará en la vía arbitral. En este caso, las partes quedan habilitadas para iniciar inmediatamente el arbitraje.

2. Por el resultado del trámite:

a) Total: Cuando las partes se han puesto de acuerdo respecto de todos los puntos relativos a su conflicto de intereses y señalados como tales en la solicitud de conciliación y a lo largo del procedimiento conciliatorio.

b) Parcial: Cuando las partes se han puesto de acuerdo respecto de alguno o algunos de los puntos controvertidos, dejando otros sin resolver; o cuando, existiendo una pluralidad de sujetos, existe acuerdo conciliatorio sólo entre algunos de ellos. 
c) Falta de acuerdo entre las partes.

d) Inasistencia de una parte a dos (2) sesiones.

e) Inasistencia de las partes a una (1) sesión.

Artículo $8^{\circ}$. - Con relación a la confidencialidad que dispone el Artículo $8^{\circ}$ de la ley, entiéndase que todo lo sostenido o propuesto en el proceso de conciliación carece de valor probatorio en cualquier proceso judicial o arbitraje que se promueva posteriormente, aún en aquellos que se originen en hechos distintos a los que dieron origen a la controversia materia de conciliación.

Constituyen excepciones a la regla de la confidencialidad el conocimiento en el procedimiento de conciliación de la inminente realización de un delito, o ante uno ya consumado. En estos casos, el conciliador debe poner el hecho en conocimiento de las autoridades pertinentes.

El conciliador que viole el principio de confidencialidad será sancionado, según la gravedad de su falta, con multa, suspensión de seis meses a un año o inhabilitación permanente para desempeñarse como conciliador, sin perjuicio de la responsabilidad civil que exista. Las sanciones serán impuestas por el Ministerio de Justicia.

Si el conciliador viola el principio de confidencialidad, la responsabilidad del Centro de Conciliación se rige, analógicamente, por lo dispuesto en el Artículo $1325^{\circ}$ del Código Civil. Todo pacto que exima de responsabilidad al Centro de Conciliación, en este sentido, es nulo.

Artículo $9^{\circ}$. Para efectos de lo dispuesto en el Artículo $9^{\circ}$ de la ley, se entiende como pretensión determinada aquella por la cual se desea satisfacer un interés que ha sido perfectamente fijado en la solicitud de conciliación.

La pretensión es determinable cuando ésta es susceptible de fijarse con posterioridad a la presentación de la solicitud de conciliación.

No existe inconveniente para que, en el desarrollo de la conciliación, el conciliador y las partes den un contenido diferente a las pretensiones determinadas o determinables inicialmente previstas. En este caso, el acuerdo conciliatorio deberá referirse a estas últimas.

Artículo $10^{\circ}$. - Cuando la ley señala en su Artículo 9o que son conciliables las pretensiones que versen sobre violencia familiar, debe entenderse que es posible sólo conciliar sobre los motivos o factores que generen la violencia, no siendo posible conciliar respecto de la intensidad de la misma. 
Debe tenerse en cuenta que, en estos casos, el fin de la conciliación es el cese definitivo de los actos de violencia, por lo que es nulo cualquier acuerdo que implique la renuncia de derechos o legitimen los actos de violencia.

Artículo $11^{\circ}$.- Tratándose de los procedimientos cautelares iniciados antes del proceso principal, el solicitante de la medida tendrá un plazo de cinco (5) días calendario, comenzados a contar desde el momento en que se ejecute la medida cautelar, para solicitar la Conciliación.

Si la Conciliación es total, el solicitante deberá pedir de inmediato que se deje sin efecto la medida cautelar. Si no hay acuerdo, o éste es parcial, el plazo previsto para interponer la demanda, señalado en el Artículo $636^{\circ}$ del Código Procesal Civil, empezará a correr desde la fecha del Acta de conciliación.

Artículo $12^{\circ}$.- La solicitud de conciliación deberá presentarse por escrito y contendrá:

1. El nombre, denominación o razón social, datos de identidad, domicilio del o de los solicitantes. En el caso que desee ser invitado en una dirección diferente, deberá señalarlo en la solicitud.

2. El nombre y domicilio del representante del solicitante o solicitantes, de ser el caso.

3. El nombre, denominación o razón social y domicilio o la del centro de trabajo de la persona o de las personas con las que se desea conciliar.

4. Los hechos que dieron lugar al conflicto, expuestos en forma precisa.

5. La pretensión, indicada con orden y claridad.

6. La firma del solicitante; o su huella digital, si es analfabeto.

La solicitud de conciliación podrá realizarse también verbalmente. Para este efecto, los Centros de Conciliación elaborarán formatos de la solicitud de conciliación, los que deberán contener todos los requisitos señalados en el párrafo anterior. En este caso, todos los datos serán requeridos directamente por el conciliador o el Juez de Paz Letrado, bajo su responsabilidad.

Si el solicitante desconoce el domicilio o la del centro de trabajo de la parte con la que debe conciliar, señalará este hecho en su solicitud. En este caso, el Centro de Conciliación o el Juez de Paz Letrado, según corresponda, extenderá el Acta declarando que la Conciliación no se ha realizado. 
La demanda que se interponga sobre la base del Acta a que se refiere el párrafo anterior, será declarada inadmisible por el Juez, cuando en ella se consigne la dirección de la parte con la que se debía conciliar. El demandante, en este caso, queda obligado a iniciar un nuevo procedimiento de Conciliación. La misma regla deberá aplicarse cuando el domicilio del demandado, consignado en la demanda, es diferente al señalado por el demandante en la solicitud de Conciliación no habiéndose realizado ésta por haberse constatado en el acto de invitación efectuado por el Centro de Conciliación que el invitado no domiciliaba en ese lugar.

Artículo 130.- A la solicitud de Conciliación se deberá acompañar:

1. Copia simple del documento de identidad del solicitante o solicitantes $y$, en su caso, del representante.

2. El documento que acredita la representación.

3. Copias simples del documento o documentos relacionados con el conflicto.

4. Tantas copias simples de la solicitud, y sus anexos, como invitadas a conciliar.

Tratándose de régimen de visitas y violencia familiar y de aquellos asuntos cuya cuantía no exceda de 10 URP, los Centros de Conciliación y los Jueces de Paz Letrados darán fe de la autenticidad de los documentos originales, sin necesidad de dejar copia. Este servicio es gratuito.

Artículo $14^{\circ}$.- Recibida la solicitud, el Centro de Conciliación deberá designar en el día al conciliador y éste, invitará a las partes, para la audiencia, dentro de los cinco días útiles siguientes.

Artículo $15^{\circ}$.- Las invitaciones deberán redactarse en forma clara, sin emplear abreviaturas, y contendrán:

1. El nombre, denominación o razón social de la persona o personas a invitar y el domicilio.

2. La denominación o razón social y dirección del Centro de Conciliación o del Juzgado de Paz Letrado.

3. El nombre, denominación o razón social del solicitante de la Conciliación.

4. El asunto sobre el cual se pretende conciliar.

5. Copia simple de la solicitud de conciliación.

6. Información relacionada con la Conciliación en general y sus ventajas en particular. 
7. Día y hora para la Audiencia de Conciliación.

8. Fecha de la invitación.

9. Firma del conciliador.

Artículo $16^{\circ}$.- La invitación podrá efectuarla el Juzgado de Paz Letrado, un empleado del Centro de Conciliación o una empresa especializada contratada por éste, y deberá entregarse en el domicilio señalado por el solicitante. El responsable de cursar la invitación dejará constancia escrita del nombre, firma e identificación del receptor. En caso de negativa a recibir la invitación por no domiciliar o no laborar el destinatario en el lugar, el responsable dejará constancia escrita de este hecho.

Artículo $17^{\circ}$.- Para la realización de la Audiencia de Conciliación deberán observarse las siguientes reglas:

1. Las partes pueden estar asesoradas por personas de su confianza, sean letrados o no. El conciliador no permitirá su presencia en el ambiente donde se lleve a cabo la Conciliación cuando, a su juicio, perturben o impidan el desarrollo de la misma, o cuando su presencia sea objetada por la otra parte sin necesidad de expresión de causa. Los asesores, cuando su presencia se admita, podrán ser consultados por las partes, pero no tendrán derecho a voz ni podrán interferir en las decisiones que se tomen.

2. Si la Audiencia se lleva a cabo en más de una sesión, deberá dejarse expresa constancia de la interrupción en el Acta respectiva, señalándose en ese momento el día y hora en que continuará la Audiencia. La sola firma de las partes en el Acta significa que han sido debidamente invitadas para la siguiente sesión.

3. Si ninguna de las partes acude a la primera sesión, no debe convocarse a más sesiones, dándose por concluido el procedimiento de conciliación.

4. Cuando las partes asisten a la primera sesión, el conciliador debe promover el diálogo y eventualmente proponerles fórmulas conciliatorias no obligatorias. Si al final de dicha sesión, las partes manifiestan su deseo de no conciliar, la Audiencia y el procedimiento de conciliación deben darse por concluidos.

5. Cuando sólo una de las partes acude a la primera sesión, deberá convocarse a una segunda. Si la situación persiste en la segunda sesión, deberá darse por concluida la Audiencia y el procedimiento de conciliación. 
6. Cuando cualquiera de las partes deja de asistir a dos sesiones alternadas o consecutivas, el conciliador debe dar por concluida la Audiencia y el procedimiento de conciliación.

Concluido el procedimiento de conciliación, el Centro queda obligado a otorgar inmediatamente, a cada una de las partes, copia del Acta.

Artículo 180.- Tratándose de la Conciliación ante un Centro, para todos los efectos, debe entenderse que Lima y Callao son un solo distrito conciliatorio. En el resto del país se considerará a cada provincia como un distrito conciliatorio.

Las demás disposiciones sobre competencia territorial, contenidas en el Código Procesal Civil, se aplican supletoriamente para la Conciliación ante el Juez de Paz Letrado y ante los Centros de Conciliación, en lo que fueran pertinentes.

Ninguna de las reglas anteriores rige cuando la presentación de la solicitud es conjunta. En este caso, las partes pueden elegir, con libertad, el Centro de Conciliación ante el cual plantearán su solicitud.

Artículo $19^{\circ}$.- El acto conciliatorio es eminentemente personal. Excepcionalmente, y en aplicación del Artículo $14^{\circ}$ de la ley, se admite la representación para los casos allí señalados.

La representación en el procedimiento de conciliación supone la declaración de voluntad del representante que interviene a nombre, por cuenta y en interés del representado, surtiendo su declaración efectos directos respecto del representado.

Cuando se requiera, el poder deberá estar debidamente traducido, no siendo necesaria, su aceptación.

Artículo $20^{\circ}$. Las personas domiciliadas en el extranjero pueden facultar a un representante para conciliar, de acuerdo con el segundo párrafo del Artículo $14^{\circ}$ de la ley.

Artículo $21^{\circ}$.- Tanto para las personas naturales, como para las jurídicas, debe entenderse que los poderes en los que se hubiera otorgado facultades especiales de representación procesal para conciliar, llevan implícita la facultad de conciliar extrajudicialmente, salvo que se exprese lo contrario. Lo mismo se aplica a los contratos de mandato con representación.

Artículo $22^{\circ}$.- El gerente general o los administradores de las sociedades reguladas en la Ley General de Sociedades; así como el administrador, representante legal o presidente del Consejo Directivo de las 
personas jurídicas reguladas en la Sección Segunda del Libro I del Código Civil, tienen, por el sólo mérito de su nombramiento, la facultad de conciliar extrajudicialmente. La representación se acredita con la copia notarialmente certificada del documento donde conste el nombramiento, debidamente inscrito.

Articulo $23^{\circ}$.- En la conciliación sobre asuntos de violencia familiar, el conciliador debe observar las siguientes pautas:

1. Entrevistarse antes de la Audiencia de Conciliación con la víctima y el agresor, por separado, para evaluar la situación de ambos y determinar así la conveniencia de la realización o no de la Audiencia.

2. Informar a la víctima sobre sus derechos, los fines y alcances de la Conciliación, así como otras alternativas de solución al conflicto.

3. Velar antes, durante y finalizada la Audiencia, por la seguridad de la víctima, minimizado los riesgos que pudieran producirse a raíz de su intervención.

4. Promover, cuando sea necesario, que se dicten las medidas de protección o cautelares que salvaguarden la seguridad de la víctima.

5. Cuidar que la víctima participe libremente en la Audiencia de Conciliación, sin coacción de ninguna clase. En caso contrario, el conciliador deberá suspender el procedimiento hasta que existan las condiciones que garanticen la libre decisión de la víctima.

Artículo $24^{\circ}$.- De conformidad con el Artículo $16^{\circ}$ de la ley, el Acta de Conciliación es el documento que expresa la manifestación de voluntad de las partes de la Conciliación. Puede contener el acuerdo conciliatorio, sea éste total o parcial.

Si el acuerdo conciliatorio es parcial, deberán quedar claramente delimitados y descritos, en el Acta, los puntos respecto de los cuales no se hubiera llegado a solución alguna.

La verificación de la legalidad del acuerdo conciliatorio deberá efectuarla el abogado del Centro de Conciliación.

Si la Conciliación no se ha realizado, sólo deberá dejarse constancia en el Acta del hecho que lo motivó, cuando se deba a inasistencias de ambas partes a una sesión, a inasistencia de una de las partes a dos sesiones, por desconocimiento de la dirección domiciliaria de la parte con la que se quiere conciliar o por no haber sido ubicada en el domicilio señalado en la solicitud la persona con la que se pretende conciliar. De ninguna manera se dejará constancia de las propuestas o la posición de las partes. 
Articulo $25^{\circ}$.- Si el acta es nula por falta de cumplimiento de los requisitos señalados, el Centro de Conciliación de oficio o a pedido de parte, invitará a una nueva Audiencia, en la que se expedirá otra Acta que cumpla con todas las formalidades.

Artículo $26^{\circ}$. Para los efectos de lo señalado en el numeral $5 \mathrm{del}$ Artículo $16^{\circ}$ de la ley, debe entenderse que los derechos, deberes u obligaciones ciertas, expresas y exigibles son:

1. Ciertas, cuando están perfectamente descritas en el Acta de Conciliación. No existe inconveniente alguno para que las prestaciones convenidas sean genéricas.

2. Expresas, cuando constan por escrito en dicha Acta.

3. Exigibles, cuando las partes señalan el momento a partir del cual cada una de ellas puede solicitarle a la otra el cumplimiento de lo acordado. Deberá señalarse también, con claridad, el lugar y modo que se cumplirá lo acordado.

Artículo $27^{\circ}$.- De conformidad con el Artículo $18^{\circ}$ de la ley, el Acta que contenga el acuerdo conciliatorio constituye "Título de Ejecución". En tal virtud, cualquiera de las partes o de los sujetos que la integran puede exigir, ante el órgano jurisdiccional correspondiente, el cumplimiento de lo convenido, siguiendo el proceso previsto en el Artículo $713^{\circ}$ y siguientes del Código Procesal Civil.

A la demanda debe acompañarse copia del Acta de Conciliación y el documento al que se refiere el numeral 1 del Artículo $425^{\circ}$ del Código Procesal Civil; y cuando corresponda, el documento y la prueba señalados en los numerales 2 y 3 del citado artículo.

Interpuesta la demanda ante el Juez competente, éste deberá expedir el mandato de ejecución. Se declarará inadmisible la demanda si el Acta adolece de alguna de las formalidades solemnes señaladas en la ley.

Artículo $28^{\circ}$. - De acuerdo con lo señalado en el Artículo $19^{\circ}$ de la ley, los plazos de prescripción y de caducidad establecidos en el Código Civil se reinician en la fecha de conclusión de la Audiencia de Conciliación señalada en el Acta para los casos en que la conciliación fuese parcial o no se hubiera realizado.

Entiéndase extendido lo dispuesto en el artículo $19^{\circ}$ de la Ley, para las normas específicas sobre prescripción y caducidad en materia laboral; así como para el plazo establecido para impugnar una resolución administrativa en el inciso 3) del Artículo $541^{\circ}$ del Código Procesal Civil. 
Artículo $29^{\circ}$.- Las conciliaciones efectuadas por las partes, en asuntos relacionados con el derecho de familia, deberán ser integradas a la propuesta de convenio de separación convencional que las partes puedan presentar con posterioridad al juez, de acuerdo con el Artículo 575 del Código Procesal Civil. Tratándose de una pretensión de divorcio la copia certificada del Acta de Conciliación deberá anexarse a la demanda.

\section{Título III.- Del Conciliador y su capacitación}

Artículo $30^{\circ}$.- Es conciliador la persona que ejerce dicha función en los Centros correspondientes. Para ejercerla debe cumplir con los requisitos establecidos por la ley y el reglamento y haber sido acreditado como conciliador por el Ministerio de Justicia.

Artículo $31^{\circ}$.- Para el cumplimiento de sus funciones, el conciliador deberá:

1. Analizar la solicitud de conciliación con la debida anticipación.

2. Cumplir con los plazos establecidos en el Artículo $12^{\circ}$ de la ley en el Artículo $14^{\circ}$ del reglamento.

3. Informar a las partes sobre el procedimiento de conciliación, su naturaleza, características, fines y ventajas. Asimismo, deberá señalar a las partes las normas de conducta que deben observar.

4. Facilitar el diálogo entre las partes, permitiendo que se expresen con libertad y se escuchen con respeto.

5. Preguntar a las partes en relación con lo que estuvieran manifestando, con la finalidad de aclarar el sentido de alguna afirmación o para obtener mayor información que beneficie al procedimiento de conciliación.

6. Identificar el o los problemas centrales y concretos sobre los que versará la Conciliación.

7. Tratar de ubicar el interés de cada una de las partes.

8. Enfatizar los intereses comunes de las partes.

9. Incentivar a las partes a buscar soluciones satisfactorias para ambas. Eventualmente, si así lo estima conveniente, les propondrá fórmulas conciliatorias no obligatorias.

10. Reunirse con cualquiera de las partes por separado cuando las circunstancias puedan afectar la libre expresión de las ideas de alguna de ellas.

11. Informar a las partes sobre el alcance y efectos del acuerdo conciliatorio antes de su redacción final. 
12. Consultar con el abogado designado la legalidad del acuerdo conciliatorio.

13. Redactar el Acta de Conciliación, cuidando que el acuerdo conciliatorio conste en forma clara y precisa.

Artículo $32^{\circ}$.- La libertad de acción a que hace referencia el Artículo $21^{\circ}$ de la ley tiene como límites naturales el orden público, las buenas costumbres y la ética en el ejercicio de la profesión del conciliador. La ética del conciliador transita por:

1. El respeto a la solución del conflicto al que deben arribar voluntaria y libremente las partes.

2. El desarrollo de un procedimiento de conciliación libre de presiones, con participación de las partes, y el comportamiento objetivo e íntegro del conciliador, dirigido a la obtención de un acuerdo satisfactorio para ambas.

3. El respeto al Centro de Conciliación en el que presta sus servicios, absteniéndose de usar su posición para obtener ventajas adicionales a la de su remuneración.

Artículo $33^{\circ}$.- Adicionalmente a los requisitos generales que señala la ley, el conciliador deberá cumplir las siguientes condiciones:

1. Trayectoria ética y moral.

2. Acreditar capacitación y entrenamiento en técnicas de conciliación, de acuerdo con lo establecido en el artículo siguiente.

Artículo 34\%. - Para efectos de lo dispuesto en el Artículo $22^{\circ}$ de la ley, se entenderá que el conciliador se encuentra capacitado para conciliar, si aprueba los cursos que impartirá para tal efecto el Ministerio de Justicia, o acredita capacitación y experiencia en técnicas de conciliación, adquiridas en entidades reconocidas en la materia.

El Ministerio de Justicia podrá autorizar mediante Resolución Ministerial a entidades de derecho privado o público, entre ellas, Universidades, Colegios Profesionales en general, Instituciones especializadas y Centros de Conciliación con el objeto que capaciten conciliadores.

Los Centros de Conciliación reconocidos por el Ministerio de Justicia para capacitar conciliadores, deberán ser previamente autorizados por el Ministerio de Educación como Centros de Capacitación.

Artículo $35^{\circ}$. - Los cursos de capacitación para conciliadores dictados por el Ministerio de Justicia, o por las entidades autorizadas para capacitar, deberán tener un mínimo de 40 horas lectivas debiendo comprender, entre otros, los siguientes temas: 
1. Teoría de los conflictos.

2. Medios alternativos de resolución de conflictos.

3. Cuestiones jurídicas relacionadas con la conciliación.

4. Negociación.

5. Técnicas de conciliación.

6. Ética y conciliación.

7. Visión general sobre conciliación especializada.

La capacitación adquirida con anterioridad a la ley, en entidades nacionales especializadas en la materia, o en el extranjero, será evaluada por el Ministerio de Justicia con el objeto de otorgar la acreditación correspondiente al conciliador.

Artículo $36^{\circ}$.- Los conciliadores designados por un Centro de Conciliación para conducir Audiencias de Conciliación, en asuntos relacionados con el derecho de familia, deberán tener una capacitación adicional de 8 horas lectivas como mínimo, en temas relacionados con la problemática de la familia y la violencia familiar.

Artículo $37^{\circ}$.- Para ser acreditados como conciliadores, los candidatos que no tengan experiencia previa, deberán aprobar ante el Ministerio de Justicia, o las entidades autorizadas para capacitar, además de los cursos mencionados en el Artículo $35^{\circ}$ del Reglamento, una evaluación práctica que permita calificar sus habilidades conciliatorias en Audiencias de Conciliación simuladas.

Artículo $38^{\circ}$.- Constituyen impedimento, recusación y abstención para el conciliador las causales establecidas en el Código Procesal Civil.

La solicitud de recusación al conciliador, deberá ser presentada ante el Centro de Conciliación hasta 24 horas antes de la fecha de la Audiencia. En este caso, el Centro de Conciliación asignará inmediatamente otro conciliador, manteniéndose el mismo día y hora fijado para la Audiencia.

El conciliador que tenga algún impedimento deberá abstenerse de actuar en la conciliación.

Artículo $39^{\circ}$. - Si el conciliador es abogado colegiado, ejercerá doble función en la conciliación, la de conciliador y la de supervisor de la legalidad de los acuerdos.

Artículo $40^{\circ}$.- Con posterioridad al procedimiento de conciliación, quien actuó como conciliador queda impedido de ser juez, árbitro, testigo, abogado o asesor en el proceso que se promueva a consecuencia de la falta de acuerdo conciliatorio o del acuerdo parcial. 
Artículo $41^{\circ}$.- El conciliador que incumpla con las obligaciones que le asigna la ley y el reglamento será sancionado, según la gravedad de su falta y sus antecedentes, con amonestación escrita, multa, suspensión de uno a seis meses o inhabilitación permanente para desempeñarse como conciliador.

El Centro de Conciliación, bajo responsabilidad, tiene la obligación de comunicar inmediatamente la falta del conciliador al Ministerio de Justicia, encargado de imponer la sanción.

Título IV.- De los Centros de Conciliación

Artículo $42^{\circ}$.- Pueden constituirse personas jurídicas sin fines de lucro que tengan por objeto ejercer función conciliadora. Asimismo, pueden crear Centros de Conciliación las personas jurídicas de derecho público o privado, sin fines de lucro.

En ambos casos, para obtener la autorización de funcionamiento, deberán presentar una solicitud dirigida al Ministerio de Justicia, señalando la sede del Centro.

A la solicitud se acompañarán los documentos a que se refieren los dos artículos siguientes, según corresponda.

Artículo $43^{\circ}$.- Si el Centro de Conciliación es una persona jurídica, a la solicitud acompaña:

1. Certificado de inscripción de la persona jurídica en los Registros Públicos.

2. El estatuto en que conste, que tiene entre sus finalidades el ejercicio de la función conciliadora. En el estatuto, deberá estar señalado los objetivos del Centro, sus funciones, la designación de sus directores y demás cargos directivos, así como sus funciones y forma de elección.

3. Los documentos que acrediten la representación de no haber sido otorgada ésta en la misma sesión que se aprobaron los estatutos.

4. El reglamento del Centro de Conciliación.

5. La relación de conciliadores acreditados como tales por el Ministerio de Justicia.

Artículo $44^{\circ}$ - - Si el Centro de Conciliación es una entidad distinta a la persona jurídica que lo constituye, a la solicitud se deberá acompañar:

1. Certificado de inscripción en los Registros Públicos de la persona jurídica que ha constituido el Centro. 
2. Estatuto de la persona jurídica que ha constituido el Centro en los que conste, que tiene entre sus finalidades el ejercicio de la función conciliadora.

3. El Acta de Constitución del Centro de Conciliación en la que en principio deberán estar señalados sus objetivos, funciones, designación de sus directores y demás cargos directivos, así como sus funciones y forma de elección. Si todo o parte de lo mencionado no constara en esta Acta, deberá acompañarse el o los documentos que contengan dicha información.

4. Los documentos que acrediten la representación, en caso de no haber sido otorgada en la misma sesión en que se aprobó la constitución del Centro.

5. El Reglamento del Centro de Conciliación.

6. La relación de conciliadores acreditados como tales por el Ministerio de Justicia.

Artículo 450.- En todos los casos se deberá acompañar a la solicitud, adicionalmente:

1. La descripción de la sede del Centro y sus instalaciones e infraestructura básica, la que deberá constar de por lo menos dos ambientes.

2. El nombre del abogado o abogados que supervisarán la legalidad de los acuerdos conciliatorios.

Artículo 46 .- Los Centros de Conciliación que se constituyan en provincias presentarán su solicitud ante la entidad que para tal caso señalará el Ministerio de Justicia por Resolución Ministerial. Dicha entidad será la encargada de aprobar la solicitud, pudiéndose encargar también la supervisión de los Centros de su zona.

Artículo $47^{\circ}$.- Recibida la solicitud, el Ministerio de Justicia verificará en el plazo de siete días útiles, la documentación entregada. Si la documentación no es suficiente, dentro de los tres días útiles siguientes a la verificación. Oficiará al solicitante para que complete la información o presente los documentos que le sean indicados. Si dentro de los diez días útiles, el notificado no completa la documentación, opera automáticamente el abandono de la solicitud presentada.

Si la documentación es suficiente, el Ministerio de Justicia ordenará dentro de los tres días útiles de efectuada la verificación, que se lleve a cabo una inspección en la sede del solicitante, a fin de constatar que las instalaciones sean adecuadas. La inspección deberá realizarse dentro de los siete días útiles, siguientes a la fecha del oficio remitido al solicitan- 
te indicando la realización de la inspección. El oficio contendrá el día y hora de dicha verificación.

Efectuada la inspección y constatado el cumplimiento de los requisitos establecidos por la ley y el presente reglamento, el Ministerio de Justicia expedirá la resolución concediendo la autorización de funcionamiento, la misma que deberá ser publicada en el Diario Oficial «El Peruano». La resolución deberá expedirse en un plazo no mayor de 20 días calendario contados desde la fecha de la inspección. Transcurrido este plazo sin pronunciamiento del Ministerio de Justicia, se entenderá concedida la autorización.

Artículo $48^{\circ}$.- El Ministerio de Justicia dispondrá la supervisión de los Centros de Conciliación. Para este efecto podrá efectuar inspecciones en el Centro sin previo aviso. Dicha supervisión estará a velar por el cumplimiento de lo dispuesto por la ley y el presente reglamento, y a constatar, principalmente:

1. El desarrollo de los procedimientos de conciliación de acuerdo a la ley y el presente reglamento;

2. La observancia de los plazos señalados por la ley y el presente reglamento;

3. El cumplimiento del deber de capacitación permanente de los conciliadores;

4. La aplicación de los principios señalados en el Artículo $2^{\circ}$ de la ley; debiéndose considerar como falta ética la no observancia de estos principios;

5. La revisión del archivo de actas para verificar que esté siendo llevado correctamente.

El Centro de Conciliación deberá brindar todas las facilidades del caso al supervisor, quien podrá estar presente en las Audiencias de Conciliación, cuando las partes lo autoricen expresamente. El supervisor está sujeto a la obligación de confidencialidad y a respetar los principios de la conciliación que correspondan. El incumplimiento de esta obligación dará lugar a que el Ministerio de Justicia imponga las sanciones civiles y administrativas respectivas.

Artículo 49\%.- El Ministerio de Justicia constituirá el Registro Nacional de Centros de Conciliación, en el que se inscribirá de oficio a los Centros una vez expedida la resolución a que alude el Artículo $47^{\circ} \mathrm{del}$ reglamento, o a solicitud de parte en el caso de haberse producido la aprobación tácita referida en el último párrafo de dicho artículo. En el 
Registro se archivarán los documentos sustentatorios de las solicitudes formuladas por los Centros de Conciliación, se anotarán las sanciones impuestas a cada Centro o a sus conciliadores, así como los motivos que la originaron.

Cualquier cambio en relación con la información y documentación contenida en el Registro deberá ser comunicada al Ministerio de Justicia. Artículo 50 .- El Reglamento del Centro de Conciliación a que hace referencia el numeral 3, del Artículo $27^{\circ}$ de la ley, deberá normar además, lo siguiente:

1. Procedimientos para la selección, capacitación permanente y designación de los conciliadores.

2. Procedimiento que deben seguir las personas que deseen utilizar los servicios del Centro de Conciliación, anexando, de ser el caso, las tablas de honorarios del Centro y de sus conciliadores, si los servicios son onerosos, y la de gastos administrativos del Centro.

3. Normas de conducta para los conciliadores, los usuarios y el personal administrativo.

4. Procedimientos para solicitar copias de las Actas de Conciliación. Artículo $51^{\circ}$.- El Registro de Actas de Conciliación será llevado por el Centro de Conciliación. Se exige como mínimo que sus hojas estén debidamente numeradas y que, de utilizarse archivos computarizados, exista versión impresa del Registro.

Artículo 52 .- Si el Centro de Conciliación presta servicios a título oneroso, deberá elaborar una tabla de honorarios señalando los montos a pagarse por los servicios de conciliación, según la cuantía y tipo de conflicto. Tratándose de asuntos de familia, las tarifas no pueden exceder, en ningún caso, de 1 URP.

Será sancionado el Centro de Conciliación que discrimine la atención de asuntos de poca cuantía o de familia.

Artículo 53\%.- El Centro de Conciliación que incumpla con las obligaciones que le asigna la ley y el reglamento será sancionado, según la gravedad de su falta, con multa, suspensión de un mes a un año o desautorización de funcionamiento. Las sanciones serán impuestas por el Ministerio de Justicia, con arreglo al Reglamento de Sanciones a Conciliadores y Centros de Conciliación, que deberá aprobarse por Resolución Ministerial.

Artículo $54^{\circ}$. - Constituye falta al principio de veracidad, el no remitir oportunamente al Ministerio de Justicia los resultados estadísticos a 
los que hace referencia el Artículo $30^{\circ}$ de la ley, así como la tergiversación o el ocultamiento de la información cuantitativa obtenida por el Centro de Conciliación.

Artículo 55\%.- Ningún Centro de Conciliación puede cerrar sin autorización previa del Ministerio de Justicia. Autorizado el cierre, el Centro está obligado a remitir al Ministerio el Registro de Actas de Conciliación.

Título V.- De la Junta Nacional de Centros de Conciliación Artículo 56\%. La Junta Nacional de Centros de Conciliación podrá constituirse cuando existan un mínimo de diez Centros de Conciliación debidamente inscritos en el Registro Nacional de Centros de Conciliación. La Junta se constituirá como una asociación civil sin fines de lucro. Su estatuto será aprobado por los asociados fundadores, quienes serán las personas jurídicas establecidas en el Artículo $42^{\circ} \mathrm{del}$ reglamento. En su estatuto se deberá establecer que cada Centro tiene derecho a un voto.

Constituída la Junta, sus directivos quedan obligados a poner este hecho en conocimiento del Ministerio de Justicia.

Artículo $57^{\circ}$.- Autorizado el funcionamiento de un nuevo Centro de Conciliación por el Ministerio de Justicia, éste pondrá en conocimiento de la Junta la autorización concedida. Con la sola notificación se entiende que el Centro o la persona jurídica que lo constituye queda automáticamente incorporado a la Junta Nacional de Centros de Conciliación, debiendo registrarse la incorporación en el registro de asociados.

Autorizado u ordenado el cierre de un Centro de Conciliación, el mismo dejará de pertenecer a la Junta Nacional de Centros de Conciliación, a partir de la fecha de publicación, en el Diario Oficial «El Peruano», de la resolución que autoriza u ordena el cierre.

La Junta no podrá quitarle por ninguna razón su calidad de miembro de ella a ningún Centro de Conciliación mientras esté vigente su autorización de funcionamiento otorgada por el Ministerio de Justicia. Detectada alguna irregularidad, deberá ponerla en conocimiento del Ministerio de Justicia, quien tomará las medidas correspondientes, de acuerdo con lo previsto en el Artículo $26^{\circ}$ de la ley y el Artículo $53^{\circ}$ del reglamento. 
Título VI.- De la Conciliación ante los Jueces de Paz Letrado

Artículo $58^{\circ}$.- La Conciliación puede realizarse, a voluntad de parte interesada, ante el Juez de Paz Letrado.

El procedimiento de conciliación ante los Juzgados de Paz Letrado se regulará por lo dispuesto en la ley y el presente reglamento.

Artículo 59\%.- El Acta de Conciliación deberá contener los requisitos establecidos en el Artículo $16^{\circ}$ de la ley, con excepción del numeral 7, tomando en consideración lo señalado en el Artículo $25^{\circ}$ del reglamento.

El Registro de Actas de Conciliación se llevará de acuerdo a lo establecido en el Artículo $51^{\circ}$ del reglamento.

Artículo $60^{\circ}$.- Los jueces en general deberán recibir cursos de capacitación para actuar como conciliadores fuera de proceso.

Los cursos de capacitación comprendidos en el Artículo 35 del reglamento, serán desarrollados por la Academia Nacional de la Magistratura o el Ministerio de Justicia.

Título VII.- De la Conciliación en Equidad

Artículo $61^{\circ}$.- La Conciliación en Equidad se basa en el aprovechamiento de las personas notables de un grupo o de una comunidad, que por el propio conocimiento que tienen de su entorno pueden asistir con propiedad a la solución de los conflictos existentes en su grupo o comunidad.

Articulo $62^{\circ}$.- Puede ser designado como Conciliador en Equidad cualquier persona natural que acredite solvencia moral e idoneidad para dirigir el procedimiento conciliatorio, y que sea postulada para el cargo por una Comunidad Campesina o Nativa, Asentamiento Humano, Urbanización Popular, Comunidad Religiosa u organización cívica, gremial o sindical.

Articulo 63\%.- La designación de los Conciliadores en Equidad se realizará mediante Resolución Ministerial del Ministerio de Justicia. La sola designación del Conciliador en Equidad da lugar a que se entienda constituído el Centro de Conciliación de la comunidad u organización a la cual pertenece.

Articulo $64^{\circ}$.- La selección del Conciliador en Equidad debe realizarse sobre la base del pedido o de la terna presentada por las organizaciones señaladas en el Artículo $62^{\circ}$ del reglamento.

Articulo 650.- Los Conciliadores en Equidad pueden ejercer su función en todas las materias señaladas en el Artículo $9^{\circ}$ de la ley. Si la 
pretensión es apreciable en dinero, sólo podrán ejercer su función cuando la cuantía no exceda de 10 URP.

Estos conciliadores sólo podrán actuar como tales en los conflictos existentes entre los miembros de su comunidad u organización. Sin embargo, podrán hacerlo en la solución de los conflictos entre un miembro de su comunidad u organización con el de otra similar, si la otra parte conviene en ello.

Artículo $66^{\circ}$.- El Ministerio de Justicia queda encargado de promover, a nivel nacional; la postulación de Conciliadores en Equidad, y de capacitarlos adecuadamente.

Artículo $67^{\circ}$. - El procedimiento de conciliación ante los Conciliadores en Equidad se regula por lo establecido en la ley y el reglamento, siempre que no se contraponga con lo establecido en este Título.

Artículo $68^{\circ}$. - La solicitud de conciliación podrá realizarse verbalmente, debiendo el Conciliador en Equidad dejar constancia en el Acta respectiva de los requisitos mencionados en el Artículo $12^{\circ}$ del reglamento.

Artículo 69\%. - El Conciliador en Equidad dará fe de la autenticidad de los documentos originales sin necesidad que se deje copia. Este servicio es gratuito.

Artículo $70^{\circ}$.- El servicio prestado por los Conciliadores en Equidad puede ser gratuito o a título oneroso. En este último caso, la tabla de honorarios será aprobada por el Ministerio de Justicia, tomando en cuenta la materia y la cuantía.

Artículo $71^{\circ}$.- La invitación podrá realizarse con el apoyo de la Policía Nacional, de existir una delegación en la zona. En caso contrario, la podrá realizar el conciliador, o el propio interesado, cuando el caso lo amerite.

Artículo $72^{\circ}$.- El Registro Nacional de Centros de Conciliación es el encargado de inscribir a los Conciliadores en Equidad, debiéndose archivar en el Registro los documentos sustentatorios de la designación, las sanciones y los motivos que las originaron.

Articulo $73^{\circ}$.- El Registro de Actas de Conciliación debe llevarse necesariamente por escrito, y sus hojas deben estar numeradas.

Artículo $74^{\circ}$.- Los Conciliadores en Equidad que incumplan con las obligaciones que le asigna la ley y le presente reglamento serán sancionados según la gravedad de su falta y sus antecedentes con amonestación, multa, suspensión de 1 a 6 meses, o inhabilitación permanente para desempeñarse como conciliador. 
Artículo $75^{\circ}$.- Los Centros de Conciliación en Equidad no integran la Junta Nacional de Conciliación.

Disposiciones Complementarias, Transitorias y Finales

Primera.- El Ministerio de Justicia queda encargado de difundir de manera adecuada el inicio de la obligatoriedad de la Conciliación y las ventajas de la misma.

Segunda.- De acuerdo con la Cuarta de las Disposiciones Complementarias, Transitorias y Finales de la ley, y en el plazo de doce meses señalado en la misma, las entidades de reconocido prestigio que han venido realizando conciliaciones sólo tendrán que prestar una solicitud expresando su intención de adecuarse a la nueva reglamentación, señalando el lugar donde la entidad funciona, y el volumen de acuerdos logrados, mediante una Declaración Jurada de su representante legal.

La Resolución Ministerial que autoriza el funcionamiento se expedirá en un plazo de veinte días útiles. Transcurrido dicho plazo sin haberse denegado la solicitud se entenderá autorizado el funcionamiento quedando el Ministerio automáticamente obligado a inscribir al solicitante en el Registro Nacional de Centros de Conciliación.

Tercera. - Los servicios de Defensoría del Niño y el Adolescente que deseen convertirse en Centros de Conciliación, deberán optar entre ser Centro de Conciliación o Servicio de Defensoría del Niño y el Adolescente, no pudiendo asumir ambas funciones a la vez. La renuncia a seguir actuando como servicio de Defensoría del Niño y el Adolescente deberá ser presentada ante la Gerencia de Promoción de la Niñez y la Adolescencia del PROMUDEH, que deberá dar su aprobación; comunicándolo de inmediato al Ministerio de Justicia.

Cuarta.- El Ministerio de Justicia aprobará mediante Resolución Ministerial los modelos de Reglamento Tipo de los Centros de Conciliación, Formato Tipo de la invitación y Formato Tipo del Acta de Conciliación.

Mediante Resolución Ministerial, el Ministerio de Justicia podrá, además, dictar las medidas complementarias y las directivas necesarias para facilitar la aplicación de la ley y el reglamento, así como la adecuada implementación de la Conciliación como mecanismo extrajudicial o alternativo de solución de conflictos.

Quinta.- El Ministerio de Justicia, mediante Resolución Ministerial, aprobará el Reglamento de los Centros de Conciliación en Equi- 
dad, y dictará las medidas necesarias para la implementación y regulación de la Conciliación en Equidad.

Sexta.- El Ministerio de Justicia, podrá, mediante Resolución Ministerial, delegar en las entidades públicas o privadas que estime convenientes las facultades que le otorga la ley y el presente reglamento."

Reglamento de Conciliación del Centro de Conciliación y Arbitraje de la Cámara de Comercio de Lima

Aplicación del reglamento Artículo $1^{\circ}$

1. Este Reglamento se aplicará a la conciliación de controversias que deriven de una relación contractual y otro tipo de relación jurídica, o se vinculen con ella, cuando las partes que procuren llegar a una solución amistosa de su controversia hayan acordado aplicar el Reglamento de Conciliación del Centro de Arbitraje de la CCL.

2. Las partes podrán acordar, en cualquier momento, la exclusión o modificación de cualquiera de estas reglas.

3. Cuando alguna de estas reglas esté en conflicto con una disposición del derecho que las partes no puedan derogar, prevalecerá esa disposición.

Inicio del procedimiento de Conciliación Articulo $2^{\circ}$

1. La parte que tome la iniciativa de la conciliación enviará, por escrito, a la otra parte una invitación a la conciliación de conformidad con el presente Reglamento, mencionando brevemente el asunto objeto de controversia.

2. El procedimiento conciliatorio se iniciará cuando la otra parte acepte la invitación a la conciliación. Si la aceptación se hiciese oralmente, es aconsejable que se confirme por escrito.

3. Si la otra parte rechaza la conciliación, no habrá procedimiento conciliatorio.

* Tomado de Normas Legales, Tomo 260, Enero 1998, pp. 155-163. 
4. La parte que inicie la conciliación si no recibe respuesta dentro de los 30 días siguientes al envío de la invitación, o dentro de otro período de tiempo especificado en ella, tendrá la opción de considerar esa circunstancia como rechazo de la invitación a la conciliación. Si decide considerarla como tal, deberá comunicarlo a la otra parte.

Número de conciliadores

Artículo $3^{\circ}$

Habrá un conciliador, a menos que las partes acuerden que sean dos o tres los conciliadores. Cuando haya más de un conciliador deberán, por regla general, actuar de común acuerdo.

Designación de los conciliadores

Artículo $4^{\circ}$

1. a)En el procedimiento conciliatorio con un conciliador, las partes procurarán ponerse de acuerdo sobre el nombre del conciliador único; b) En el procedimiento conciliatorio con tres conciliadores, cada una de las partes nombrará uno. Las partes procurarán ponerse de acuerdo sobre el nombre del tercer conciliador.

2. Las partes podrán recurrir a la asistencia de la Corte de Arbitraje del Centro de Arbitraje de la CCL en relación con el nombramiento de conciliadores. En particular,

a) Una parte podrá solicitar a la Corte que recomiende los nombres de personas idóneas que podrían actuar como conciliadores; o

b) Las partes podrán convenir en que el nombramiento de uno o más conciliadores sea efectuado directamente por la Corte de Arbitraje.

$\mathrm{Al}$ formular recomendaciones o efectuar nombramiento de personas para el cargo de conciliador, la Corte de Arbitraje tendrá en cuenta las consideraciones que puedan garantizar el nombramiento de un conciliador independiente e imparcial y, con respecto a un conciliador único o un tercer conciliador, tendrá en cuenta la conveniencia de nombrar un conciliador de nacionalidad distinta a las nacionalidades de las partes, si fuera el caso.

Presentación de documentos al conciliador Artículo $5^{\circ}$

1. El conciliador (se aplica ya sea un conciliador único o a dos o tres 
conciliadores, según sea el caso), después de su designación, solicitará de cada una de las partes que le presente una sucinta exposición por escrito describiendo la naturaleza general de la controversia y los puntos en litigio. Cada parte enviará a la otra un ejemplar de esta exposición.

2. El conciliador podrá solicitar de cada una de las partes una exposición adicional, por escrito, sobre su respectiva exposición y sobre los hechos y motivos en que ésta se funda, acompañada de los documentos y otros medios de prueba que cada parte estime adecuados.

3. El conciliador podrá, en cualquier etapa del procedimiento conciliatorio, solicitar de una de las partes la presentación de otros documentos que estimase adecuados.

Representación y asesoramiento Articulo $6^{\circ}$

Las partes podrán hacerse representar o asesorar por personas de su elección. Los nombres y las direcciones de esas personas deberán comunicarse por escrito a la otra parte y al conciliador; esa comunicación deberá precisar si la designación se hace a efectos de representación o de asesoramiento.

Función del conciliador Articulo $7^{\circ}$

1. El conciliador ayudará a las partes de manera independiente e imparcial en sus esfuerzos por lograr un arreglo amistoso de la controversia.

2. El conciliador se atendrá a principios de objetividad, equidad y justicia, teniendo en cuenta, entre los factores, los derechos y las obligaciones de las partes, los usos del tráfico mercantil de que se trate y las circunstancias de la controversia, incluso cualesquiera prácticas establecidas entre las partes.

3. El conciliador podrá conducir el procedimiento conciliatorio en la forma que estime adecuada, teniendo en cuenta las circunstancias del caso, los deseos que expresen las partes, incluida la solicitud de cualquiera de ellas de que el conciliador oiga declaraciones orales, y la necesidad de lograr un rápido arreglo de la controversia.

4. El conciliador podrá, en cualquier etapa del procedimiento conciliatorio, formular propuestas para una transacción de la controver- 
sia. No es preciso que esas propuestas sean formuladas por escrito ni que se aplique el fundamento de ellas.

Asistencia administrativa

Artículo $8^{\circ}$

Con el fin de facilitar el desarrollo del procedimiento conciliatorio, las partes, o el conciliador con la conformidad de éstas, podrán disponer la prestación de asistencia administrativa por la Secretaría General del Centro de Arbitraje de la CCL.

Comunicación entre el conciliador y las partes Artículo 9

1. El conciliador podrá invitar a las partes a reunirse con él o comunicarse con ellas oralmente o por escrito. Podrá reunirse o comunicarse con las partes conjuntamente o con cada una de ellas por separado.

2. A falta de acuerdo entre las partes respecto del lugar en que hayan de reunirse con el conciliador, éste será la sede del Centro de Arbitraje de la CCL.

Revelación de información

Articulo $10^{\circ}$

Si el conciliador recibe de una de las partes información de hechos relativos a la controversia, revelará su contenido a la otra parte a fin de que ésta pueda presentarle las explicaciones que estime convenientes. Sin embargo, si una parte proporciona información al conciliador bajo la condición expresa de que se mantenga confidencial, el conciliador no revelará esa información.

Colaboración de las partes con el conciliador Articulo $11^{\circ}$

Las partes colaborarán de buena fe con el conciliador y, en particular, se esforzarán en cumplir las solicitudes de éste de presentar documentos escritos, aportar pruebas y asistir a las reuniones.

Sugerencias de las partes para la transacción de la controversia Artículo $12^{\circ}$

Cada una de las partes, a iniciativa propia o a invitación del conci- 
liador, podrá presentar a éste sugerencias para la transacción de la controversia.

Acuerdo de transacción

Artículo $13^{\circ}$

1. Cuando el conciliador estime que existen elementos para una transacción aceptable por las partes, formulará los términos de un proyecto de transacción y los presentará a las partes para que éstas expresen sus obligaciones. A la vista de estas observaciones, el conciliador podrá formular nuevamente otros términos de posible transacción.

2. Si las partes llegan a un acuerdo sobre la transacción de la controversia, redactarán y firmarán un acuerdo escrito de transacción. Si las partes así lo solicitan, el conciliador redactará el acuerdo de transacción o ayudará a las partes a redactarlo. (Las partes podrán considerar que en el acuerdo de transacción se incluya una cláusula por la cual todos los litigios derivados del acuerdo de transacción o relativos a éste, deban someterse a arbitraje).

3. Las partes, al firmar el acuerdo de transacción, ponen fin a la controversia y quedan obligadas al cumplimiento de tal acuerdo.

Confidencialidad

Artículo $14^{\circ}$

El conciliador y las partes mantendrán el carácter confidencial de todas las cuestiones relativas al procedimiento conciliatorio. La confidencialidad se hará también extensiva a los acuerdos de transacción, salvo en los casos en que su revelación sea necesaria con fines de ejecución y cumplimiento.

Conclusión del procedimiento conciliatorio Artículo $15^{\circ}$

El procedimiento conciliatorio concluirá:

a) Por la firma de un acuerdo de transacción de las partes, en la fecha del acuerdo; o

b) Por una declaración escrita del conciliador hecha después de efectuar consultas con las partes en el sentido de que ya no se justifican ulteriores esfuerzos de conciliación; o

c) Por una declaración escrita dirigida al conciliador por las partes en 
el sentido de que el procedimiento conciliatorio queda concluido, en la fecha de la declaración; o

d) Por una notificación escrita dirigida por una de las partes a la otra parte y al conciliador, si éste ha sido designado, en el sentido de que el procedimiento conciliatorio queda concluido.

Si el procedimiento conciliatorio no concluyera por un acuerdo de transacción, la controversia será sometida en forma automática a un arbitraje que se desarrollará conforme al Reglamento de Arbitraje $\mathrm{Na-}$ cional o Internacional de la CCL, según corresponda, y administrado por el Centro de Arbitraje de la Cámara de Comercio de Lima.

Recurso a procedimientos arbitrales o judiciales Artículo $16^{\circ}$

Las partes se comprometen a no iniciar, durante el procedimiento conciliatorio, ningún procedimiento arbitral o judicial respecto de una controversia que sea objeto del procedimiento conciliatorio, con la salvedad de que una parte podrá iniciar un procedimiento arbitral o judicial cuando ésta estime que tal procedimiento es necesario para conservar sus derechos.

Costas

Artículo $17^{\circ}$

1. Al terminar el procedimiento conciliatorio, el conciliador liquidará las costas de la conciliación y las notificará por escrito a las partes. El término "costas" comprende exclusivamente:

a) Los honorarios del conciliador, de acuerdo con la Tabla de Aranceles del Centro de Arbitraje de la CCL.

b) Los gastos de viaje y demás expensas del conciliador;

c) Los gastos de viaje y demás expensas de cualesquiera testigos que hubiera llamado el conciliador con el consentimiento de las partes;

d) El costo de todo asesoramiento pericial solicitado por el conciliador con el consentimiento de las partes;

2. Las costas señaladas en el párrafo precedente se dividirán por igual entre las partes, salvo que el acuerdo de transacción disponga una distribución distinta. Todos los otros gastos en que incurra una parte serán de cuenta de ella. 
Anticipos

Artículo $18^{\circ}$

1. El conciliador, una vez designado, podrá requerir de cada una de las partes que consigne una suma igual en concepto de anticipo de las costas que, de conformidad con el párrafo 1 del artículo 17, éste calcule que podrán causarse.

2. En el curso del procedimiento conciliatorio, el conciliador podrá solicitar anticipos adicionales de igual valor a cada una de las partes.

3. Si las sumas cuya consignación es requerida de conformidad con los párrafos 1 y 2 de este artículo no hubieran sido abonadas en su totalidad por ambas partes dentro del plazo de 30 días, el conciliador podrá suspender el procedimiento o presentar a las partes una declaración escrita de conclusión, que entrará en vigor en la fecha en que se haya formulado.

4. Una vez concluidos los procedimientos de conciliación, el conciliador rendirá cuenta a las partes de los anticipos recibidos y les devolverá cualquier saldo que resulte a favor de éstas.

Función de conciliador en otros procedimientos Artículo $19^{\circ}$

Las partes y el conciliador se comprometen a que el conciliador no actúe como árbitro, representante ni asesor de una parte en ningún procedimiento arbitral o judicial relativo a una controversia que hubiera sido objeto del procedimiento conciliatorio. Las partes se comprometen, además, a no llamar al conciliador como testigo en ninguno de tales procedimientos.

Admisibilidad de pruebas en otros procedimientos Artículo $20^{\circ}$

Las partes se comprometen a no invocar ni proponer como pruebas en un procedimiento arbitral o judicial, se relacionen éstos o no con la controversia objeto del procedimiento conciliatorio.

a) Opiniones expresadas o sugerencias formuladas por la otra parte respecto de una posible solución a la controversia;

b) Hechos que haya reconocido la otra parte en el curso del procedimiento conciliatorio;

c) Propuestas formuladas por el conciliador; 
d )El hecho de que la otra parte haya indicado estar dispuesta a aceptar una propuesta de solución formulada por el conciliador.

Código de ética para los árbitros y conciliadores

Articulo $1^{\circ}$.- Principio fundamental.-

1.1 Los árbitros y conciliadores actuarán con diligencia y eficacia para proporcionar a las partes un entendimiento o decisión justa y eficaz de la controversia o litigio, debiendo ser y mantenerse imparciales. Artículo $2^{\circ}$.- Aceptación del nombramiento.-

2.1 El futuro conciliador o árbitro sólo aceptará su nombramiento si está plenamente convencido que podrá cumplir su tareas con imparcialidad.

2.2 El futuro conciliador o árbitro sóloaceptará su nombramiento si está plenamente convencido que podrá resolver las cuestiones controvertidas o litigiosas y que posee un conocimiento adecuado del idioma del arbitraje correspondiente.

2.3 El futuro conciliador o árbitro sólo aceptará su nombramiento si es capaz de dedicar a la conciliación o al arbitraje el tiempo y la atención que las partes tienen derecho a exigir dentro de lo razonable.

2.4 No es correcto ponerse en contacto con las partes para solicitar un nombramiento como conciliador o árbitro.

Artículo $3^{\circ}$.- Elementos determinantes de la independencia e imparcialidad del conciliador o árbitro.-

3.1 Los criterios para evaluar las cuestiones relativas a la falta de proclividad de un conciliador o árbitro son la imparcialidad y la independencia. Se produce parcialidad cuando un conciliador o árbitro favorece a una de las partes, o cuando muestra predisposición hacia determinados aspectos correspondientes a la materia objeto de controversia o litigio. La dependencia surge de la relación entre el conciliador o árbitro y una de las partes o una persona estrechamente vinculada a ella.

3.2 Los hechos que conducirían a una persona razonable que desconozca el verdadero estado de ánimo del conciliador o árbitro a considerar que este último no es independiente respecto de una 
de las partes, generan una duda sobre su imparcialidad. Lo mismo ocurre si un conciliador o árbitro tiene interés material en el resultado de la controversia o del litigio o si ha tomado previamente posición en cuanto a éste. Estas dudas sobrela imparcialidad pueden quedar soslayadas mediante la declaración prevista en el artículo $4^{\circ}$ del presente código.

3.3 Cualquier relación de negocios en curso, directa o indirecta, que se produzca entre el conciliador o árbitro y una de las aprtes, o entre aquel y una persona que reconocidamente pueda resultar testigo sustancial para el caso, generará normalmente dudas justificadas respecto a la imparcialidad o independencia del conciliador o árbitro propuesto. Este se abstendrá de aceptar un nombramiento en tales circunstancias a menos que las partes acepten por escrito que puede intervenir. Se entiende por relaciones indirectas aquellas en que un miembro de la familia del futuro conciliador o árbitro, de su empresa o un socio comercial del mismo, mantienen relaciones de negocios con una de las partes.

3.4 Las relaciones de negocios habidas con anterioridad, no constiuirán obstáculo definitivo para la aceptación del nombramiento a menos que sean de tal magnitud o naturaleza que puedan afectar la decisión del conciliador o árbitro.

3.5 Las relaciones sociales y profesionales de carácter sustancial que se produzcan de un modo continuado entre un conciliador o árbitro y una parte o una persona cuyo testimonio pueda resultar claramente relevante para la conciliación o arbitraje, generarán dudas justificadas sobre la imparcialidad o independencia de aquel.

Artículo $4^{\circ}$.- Deber de declaración.-

4.1 El futuro conciliador o árbitro deberá revelar todos los hecho so circunstancias que puedan originar dudas justificadas respecto a su imparcialidad o independencia. El no hacerlo dará apariencia de parcialidad, lo cual puede ya servir de base para descalificación del mismo, incluso aunque los hechos o circunstancias no revelados, no justifiquen dicha descalificación.

4.2 El eventual conciliador o árbitro deberá revelar:

a) Cualquier relación de negocios, presente o pasada, directa o indirecta, según lo indicado en el artículo 3.3, incluso su designación previa como conciliador o árbitro, con cualquiera de las partes o con cualquier persona que pueda ser considerada como posible 
testigo sustancial del a conciliación oa arbitraje. En cuanto a las relaciones actuales, el deber de declaración existe cualquier que sea su importancia; en cuanto as las relaciones habidas con anterioridad, el deber sólo existe respecto de aquellas qu eno tengan carácter insignificante dados los asuntos profesionales o comerciales del conciliador o árbitro. El hecho que un futuro conciliador o árbitro no revele una de tales relacione sindierectas por resultarle desconocida no constituye causa de inhabilitación, a menos que hubiera podido ser descubierta mediante averiguaciones razonables.

b) Las características y duración de cualquier relación social sustancial mantenida con una de las partes o con una persona que puede ser considerada posible testigo sustancial en la conciliaci[ón o arbitraje.

c) Las características de cualquier relación anterior mantenida con otros conciliadores o árbitros (inclyendo los casos de previo desempeño conjunto de la función de conciliador o árbitro).

d) El alcance de cualquier conocimiento previo que haya podido tener de la controversia o litigio.

e) El alcance de cualquier compromiso que pueda afectar su disponibilidad para cumplir sus deberes como conciliador o árbitro, en la medida en que ello pueda preveerse.

4.3 El deber de declaración se mantiene durante el procedimiento conciliador o arbitral de nuevos hechos y circunstancias.

4.4 La declaración se hará por escrito y será enviada a todas la partes y a los conciliadores o árbitros.

Cuando un conciliador o árbitro recibe su nombramiento deberá comunicar a los demás conciliadores o árbitros, toda declaración que haya podido hacer a las partes con anterioridad.

Artículo $5^{\circ}$.- Comunicación con las partes.-

5.1 Durante el procedimiento conciliatorio o arbitral, el conciliador o árbitro debe evitar comunicaciones unilaterales sobre el asunto con cualquiera de las partes o sus representantes. Si tales comunicaciones tienen lugar, el conciliador o árbitro debe informar de su contenido a la otra parte o partes y a los conciliadores o árbitros.

5.2 $\mathrm{Si}$ un conciliador o árbitro tiene noticia que otro conciliador o árbitro ha mantenido contactos indebidos con algunas de las partes, puede ponerlo en conocimiento de los restantes conciliadores 
o árbitros y juntos, decidirán las medidas que deberán adoptarse. Normalmente, las medidas a adoptar consistirán inicialmente, en requeriri al conciliador o árbitro transgresor para que cese de mantener contactos indebidos con la otra parte. Si el conciliador o árbitro transgresor se niega a cesar con contactos indebidos, o simplemente persiste en el mantenimiento de los mismos, los conciliadores o árbitros restantes pueden informar a la parte ignorante a fin que ésta estudie las medidas que deben tomarse. Sólo en circunstancias extremas, el conciliador o árbitro, después de haber comunicado su intención por escrito a los restantes conciliadores o árbitros, puede unilateralmente informar a una de las partes de la conducta del otro conciliador o árbitro, a fin de permitir a dicha parte considerar la sustitución del conciliador transgresor.

5.3 Ningún conciliador o árbitro puede, directa o indirectamente, aceptar favores u hospitalidad digna de mención de alguna de las partes afectadas por la conciliación o arbitraje. Los conciliadores o árbitros únicos y los presidentes de tribunales arbitrales deben ser especialmente meticulosos en evitar contactos significativos, sociales o profesionales con cualquiera de las partes de la conciliación o arbitraje, sin la presencia de las otras partes.

Artículo 60.- Honorarios

6.1 A menos que las partes pacten otra cosa, o que en el proceso arbitral una parte se encuentre en rebeldía, el conciliador o árbitro no celebrará acuerdos unilaterales sobre gastos y honorarios.

Artículo $7^{\circ}$. Deber de diligencia

7.1 Los conciliadores o árbitros deben dedicar el tiempo y la atención que las partes pueden exigir razonablemente, de acuerdo con las circunstancias del caso, sus mejores esfuerzos en dirigir la conciliación o arbitraje de un modo tal que los costos no se eleven a una proporción irracional con respecto a los intereses en controversia o litigio.

Artículo $8^{\circ}$.- Participación en propuesta de acuerdos amistosos.-

Cuando las partes lo hayan requerido, o hayan aceptado una sugerencia del conciliador o del tribunal arbitral en tal sentido, el conciliador o tribunal en conjunto (o el Presidente del Tribunal, en su caso) pueden dirigir propuesta de arreglo a ambas partes, simultáneamente, preferentemente en presencia de las demás. Aunque previo acuerdo de 
las partes es factible cualquier procedimiento, el conciliador o tribunal arbitral debe advertir a las partes que es desaconsejable que un conciliador o árbitro discuta con una de las partes en ausencia de las otras, los términos de un arreglo, ya que normalmente ello podría determinar que el conciliador o árbitro implicado en la discusión sea descalificado para futura intervención en la conciliación o arbitraje.

Artículo 9०.- Carácter confidencial de las deliberaciones

Las deliberaciones del Tribunal Arbitral y los contenidos del laudo permanecerán confidenciales a perpetuidad a menos que las partes liberen a los árbitros de esta obligación. El árbitro no debe participar en ningún procedimiento destinado a enjuiciar el laudo ni facilitar información alguna con el propósito de facilitar tal enjuiciamiento, salvo que considere que debe revelar las conductas incorrectas o fraudulentas de cualquiera de los árbitros.

\section{Ley No 27218}

«El Presidente de la República

Por cuanto

El Congreso de la República ha dado la ley siguiente:

El Congreso de la República

Ha dado la ley siguiente:

Ley que prorroga la obligatoriedad de la Ley No 26872, Ley de Conciliación Extrajudicial

Artículo Único.- prórroga de la obligatoriedad.-

Prorrógase el carácter obligatorio de la conciliación extrajudicial a que se refiere el artículo $6^{\circ}$ de la Ley $N^{\circ} 26872$, hasta el 14 de enero del año 2001.

El Poder Ejecutivo, por Decreto Supremo, podrá disponer la conciliación extrajudicial obligatoria antes del 14 de enero del año 2001, en determinados distritos judiciales.

Comuníquese al señor Presidente de la República para su promulgación.

En Lima a los tres días del mes de diciembre de mil novecientos noventa y nueve.

Martha Hildebrandt Pérez Treviño.- Presidenta del Congreso de la República. 
Ricardo Marcenaro Frers.- Primer Vicepresidente del Congreso de la República.

$\mathrm{Al}$ señor Presidente Constitucional de la República.

Por tanto:

Mando se publique y cumpla.

Dado en la Casa de gobierno, en Lima a los nueve días del mes de diciembre de 1999.

Alberto Fujimori Fujimori. Presidente Constitucional de la República.

César Luna Victoria León. Ministro de Pesquería, Encargado de la cartera de Justicia.

* Tomado de El Peruano. Normas Legales, 12 de diciembre de 1999, p. 181339. 